\title{
ANALYSIS OF VALUES AND ATTITUDES ON MORAL ISSUES IN UNIVERSITY STUDENTS POSTGRADUATE
}

\author{
Francisco Manuel Morales Rodríguez, Maria Victoria Trianes Torres \\ University of Malaga, Malaga, Spain \\ E-mail: framorrod@uma.es, triatorr@uma.es
}

\begin{abstract}
The present study aims to provide an analysis of values and attitudes in a sample of post-graduate students and to provide an assessment of the impact and satisfaction that they had been reported in specific educational activities for solidarity. This study is framed by the project of educational innovation "A cross sectional study in education for solidarity in the training of psychologists and educators" (PIE 10-127; 2010-2012). Participants were 226 post-graduate students belonging to various specialities of the MSc in Teaching of Secondary Education and High School, Vocational Training, and Teaching Languages, aged between 22 and 49 years. The data obtained demonstrate that the majority of the interviewes strongly agree with aspects of the situation that can be considered stealing, a violent action or the avoidance of conflict. Most students graduate participants do not collaborate with NGOs; who mention the lack of time, the issue not being raised as well as not being involved in any solidarity activity noting as reasons: lack of information, idleness, not having the opportunity presented and not having the funds to do so. In addition, students have found these educational activities for solidarity very satisfactory, for example, the "discussions, work and reflection on the importance of volunteerism and solidarity in the present world" and "design of a solidarity act".
\end{abstract}

Key words: basic competence, European space of higher education, evaluation of values and attitudes, university students.

\section{Introduction}

Society demands more and more professionals know how to manage the complexity by considering the human and social aspects of such situations. The rapid development of knowledge and contexts also requires professionals to become "lifelong learners" able to update their knowledge and skills and constantly improve the quality of professional practice.

The European Higher Education has emphasized the interest in training future professionals as agents of social change, not only in reference to the creation and management of new knowledge but also in the exercise of citizens who contribute to greater social cohesion.

In times in which sometimes suffers from serious deficiencies related to the ethical implications are known which can lead to vocational or technical training that includes attention to moral and ethical dimensions of the person. There are many risks associated with not making the current scientific and technical expertise to serve purposes other than the good of the community instead 
of applying them to help transform our world and our society in a more dignified and equitable. Decision-making and ethical criteria to guide these applications depend precisely on the ethical training of persons responsible for such decisions (García Garrido, 2008) and not only their professional or scientific training.

It is also the mission of the university, and not only in compulsory education levels, training citizens to exercise civic responsibility and the commitment to the community from the field of university knowledge. In this sense, Martinez and Esteban (2005) note three reasons why the twenty-first century university education should be read in public key:

The first of them refers to a quality university education can not be reduced to training for job placement, however optimal it may be. Quality training of graduates to integrate a set of a cross sectional lessons to ensure proper, efficient and effective incorporation into the world of work, which contributes to the development and optimization of the people and society, i.e. not only must show their specific skills training environment without also other genres such as decision making, especially if they affect people or have social or ethical relevance, incorporating the social, practice teamwork, the initiative and autonomy or coexistence in heterogeneous groups. These skills affect the dimensions of the person and also allow the exercise of responsible citizenship.

1. A higher education can only be conceived as quality training if seeking social cohesion and contributes your future graduates are more involved in the promotion and development of actions aimed at increasing social inclusion. This is a training model that arises therefore as relevant learning objectives relating to the training of professionals such as those relating to the training of professionals such as those relating to the formation of citizens. The Conference of Ministers responsible for Higher Education September 19, 2003, makes that the new model of European Higher Education Area (EHEA) to build before 2010, are inseparable objectives related to achieving greater competitiveness and to greater social cohesion. In this sense, it suggests that universities should promote learning that ensure student civic competence to know how to act effectively in reducing inequalities.

2. Social inclusion, social cohesion, reducing inequalities and also the recognition of difference as a value and the struggle for equality is not easy to achieve without a citizenry committed to building a Europe of citizens and no proposals to guide the formation of citizenship.

Faced with the challenges we face in a globalized world, other authors such as Roegiers (2006) and Legendre (2007) also highlight the urgent need for higher education to prepare competent people who know their field of expertise as well as caring people can discuss current challenges and ready to engage and express themselves. Also note skills training is well understood that enables train students to become citizens able to act in the sense of their own values.

In fact, the OECD described the term competence as "the ability to respond to complex demands and carry out various tasks properly. Involves a combination of practical skills, knowledge, motivation, ethical values, attitudes, emotions and other social and behavioral components that move together to achieve effective action. "In this regard, stresses that skills to develop educational policies should respond to the complex, uncertain and changing contemporary settings with the purpose of academic learning approach to the problems and demands of contemporary life.

In Spain every university has developed various general and specific skills for each grade, although many of them have many points in common and that the Royal Decree 1393/2007 of Octuber 29, 2007, for establishing the management of official university listed in the Official Gazette (BOE) $\mathrm{n}^{\circ} 260$ instituting the core skills that must be guaranteed in the ratings. Among these are basic skills which refers to "the students have the ability to gather and interpret relevant data (usually within their field of study) to make judgments that include reflection on relevant social, scientific or ethical".

This is social or interpersonal skills such as effective communication, awareness, teamwork, promoting constructive attitudes and solidarity, respect for other cultures and traditions and citizenship, among others, which are considered basic in European Higher Education Area (EHEA) and that are key to live and work in the XXI century. In this line, in our country, Area (2004) stands out among the so-called generic skills such as those related to interpersonal ability to use communica- 
tion skills and foster critical good people interact with others, which are subdivided into individual skills related to the ability to express feelings, self-critical and critical skills as well as related social That said, the facilitation of processes of social interaction and cooperation and the promotion of education in values such as solidarity are issues that require attention from a creditable university educational practice.

Numerous recent studies (Cortina, 2000; Lind, 2007, Martinez and Hoyos, 2006, Moreno Gonzáles, 2008, Quintana, 2005; Touriñán, 2008) indicate that the binomial values are subject teach$\mathrm{ing} /$ learning process and that ethics is an essence of the person responding to a constructive nature. From this perspective, the brand or mark of responsible citizenship in socio actions does not happen naturally (incidental learning) but requires spaces that promote learning and ethics of such construction person. It is therefore necessary that the process of university education pursue the development and construction of the individual ethics in the same contexts in which they learn his profession. Values education deserves a priority in every advanced society also in the university.

In the same vein that arises before, the TUNNING project that participated in the major universities of the European Union as well as various studies on the conversation process of European convergence university (Escamez, Martinez and Ortega, 2005, Martinez and Buxarrais Esteban 2002) stresses the importance of learning these skills, though not always refer to them as ethical skills. We propose that the University should incorporate contemporary college life care community problems and issues as European citizenship is not a reality to wchich one is faced once just studies, but should be inserted into the reality training process. These studies also concrete in the space of higher education can be integrated actions and set standards or guidelines that favor the formation of values and ethical learning in five areas: a) the curriculum content, b) the forms social organization of learning tasks, c) the relationship between students and teachers, d) participatory culture and institutions, and e) the community involvement of academic learning. In such areas can be identified ethical learning processes and skills supportive of exercises or practical activities, observation, reflection and personal construction. Therefore it is appropriate to propose training actions in the contexts of the different faculties and European citizenship, and training on how to integrate ethics and practice activities and training elements of character that contribute to optimal learning and ethical citizen students.

Marked by three types of instructional theories broadly consolidated classic when it comes to supporting education in values such as solidarity and justice, such as instructional classical theory of social interaction that is most representative author Vygotsky (1935), instructional theory classical cognitive interaction defending authors as Bruner (1964) and the classical theory of instructional interaction context which is a representative author Gagné (1965). From Vygotsky's sociocultural theory proposes that the society in which it develops the subject is transmitting forms of conduct and organization of knowledge for the individual to internalize. It also points out that learning, and values such as solidarity and justice are the subject of the binomial teaching / learning takes place in society and interacting with our fellow being educationally necessary to intervene in this regard. When it comes to knowledge of socio - cultural basically refers to two things: the domain by the subject of social skills necessary to interact with others, and also the domain of tools to internalize our culture.Also from traditional instructional theories based not only on social interaction but also in cognitive interaction authors as Bruner $(1964,1966)$ indicate that the processes of information and their psychological consequence, the decision-making process, for example, those related with the issue of solidarity actions are usable from the perspective of learning and instruction because they are allowing categorisable consolidate information (whether supportive or cutting other way), it is possible to go beyond it and design schemes predictive of future events. This allows it to be greater the range of possibilities offered to the individual and the greater the scope for their needs and expectations in a teaching-learning context given. In this respect, promote skills development of solidarity in the university, also contributes to greater and richer cognitive structure of experience. With respect to the classical theory of instructional interaction context as Gagné authors proposed that each of the possible categories of learning (verbal information, intellectual skills, cognitive strategies, attitudes and skills motor) require a set of conditions to achieve optimal results. For Gagné instruction is generally defined as the set of external events to the student that are designed to support internal learning, whose use depends on the category of learning to which it refers. To promote 
attitudes of solidarity would be necessary external events such as getting attention, inform students of the objectives to achieve, presenting the encouragement with distinctive features, provide career guidance for education in values, lead to the execution or activity, provide feedback information, evaluate implementation and performance, and enhance retention and transfer of learning, in this case, the learning of values of solidarity, social justice and nonviolence.Considering these aspects, the proposed activities and those developed by graduate students has, for example, the design of acts of solidarity and work for others.

As reflected in the report headed by Delors (1997) Education is an essential tool for mankind to progress toward the ideals of: Solidarity, Peace, Freedom and Social Justice. It is a way to serve a more harmonious human development, to roll back: poverty, exclusion, misunderstanding, oppression, wars, etc. One of the keys to the twenty-first century must be a continuous structure of the human person of their knowledge and skills of their faculty of judgment. Here also evokes the concept of "Education Society", where all personal and social life may be subject to learning. It's a global experience that lasts a lifetime, at the cognitive and practical. We must all "learning to learn". Delors also clarifies that the knowledge society unavoidable arises interdependence among all professionals. In this regard, as proposed in this project very favorably evaluated by participating ANECA in a multidisciplinary group of 24 teachers from 13 different areas of teaching qualifications the University may be one of the main agents of revitalization in the development of actions solidarity and work for others. In this vein, Drucker (1993) also emphasizes the need to get the person trained, sensitive aesthetic, social and civic life. It is vital the greatest need in the globalized society, which he viewed as a knowledge society.Today there are mainly required new technical developments or further extension of existing technology, what is required are primarily trained and therefore able to take charge of the processes. This perspective opens up new horizons Drucker education to reconsider inviting the training objectives. Essentially, in the knowledge society is to learn useful knowledge for its own intrinsic value, what matters, above the particular knowledge, is learning to learn. "In the knowledge society people have to learn how to learn. Indeed, perhaps in the knowledge society imported materials unless the student's ability to continue learning and motivation. Capitalist society requires lifelong study of and be responsible and socially committed and useful to community life.For this we need a discipline of learning. Moreover, this study also requires lifelong learning is seductive, indeed, it becomes a pleasure in itself it is not because the individual yearns "(Drucker, 1993, p. 199). The latter justifies further the need to assess the impact and satisfaction that generate these educational activities for solidarity developed by students of the recent Masters of Secondary Education, as in this work.

This study is part of the innovation project "A cross sectional study about education for Solidarity of psychologists and educators" (PIE10-127, Call for Educational Innovation Projects, 20102012) coordinated by Dr. Francisco Manuel Morales Rodríguez University of Malaga. This project aims to promote general skills development solidarity, volunteering to people with disabilities and awareness in the university.

The Activities performed by students of the Master of Secondary Education were as following:

a) Discussion on the Importance of joint action in the world today, in Spanish and Andalusian school, and Dissemination of the discussions at the CSE, b) Completion of a questionnaire on moral values and attitudes toward volunteer social issues and analysis of results and activities through focus groups about the causes and consequences of the lack of solidarity, c) Conduct a survey and a self-report by the students for assessment of the impact and satisfaction, difficulty and time spent on each average activity, d) Design of an act of solidarity by students to develop a report to hang on the next course, e) Boards on various dates' for each course; f) UMA volunteer with disabled and other where there are courses voluntary no students with disabilities.

Objective of this study is to provide an analysis of values and attitudes on moral issues in this sample of graduate students as well as evaluating the impact and satisfaction that has brought them such educational activities for solidarity framed the project of Educational Innovation in which they participated.It also analyzes differences in attitudes and moral interests based on gender.

Problem of investigation: As provides in the strategic plans of the University of Malaga in the current undergraduate degree is especially relevant a more accurate assessment of attitudes and interest in moral issues and that one of the transferable skills to encourage students are social skills 
and citizens. This will enable better design of training activities in educational settings to develop these skills and social responsibilities in the university. So in our context is a priority a more accurate assessment of attitudes and interest in moral issues in graduate students of the Master of Secondary Education for the planning of educational practice criteria considering ethical and moral as part of these generic skills to be encourage European citizens.

\section{Methodology of Research}

\section{General Background of Research}

This study is part of the innovation project "Education for Solidarity in cross training of psychologists and educators" (PIE10-127, Call for Educational Innovation Projects, 2010-2012) led by Dr. Francisco Manuel Morales Rodríguez University of Malaga. This has made an accurate assessment of attitudes and interest in moral issues and an assessment of the satisfaction that educational activities in favor of solidarity has had on the students. Descriptive analyzes were performed reflecting percentages, means and standard deviations as well as applying the Student $t$ test for independent samples to see if there were significant differences in assessing attitudes and interest in moral issues based on gender.

Sample

Participants were 226 graduates students from the master in compulsory secondary school teachers and high school, vocational training and language training, specializing in foreign language (English and French), tipi (technology, computer and industrial processes), process, health and language arts, Latin and Greek aged between 22 and 49 years at the University of Málaga (123 women and 103 men). Although there are data from a sample of over 1000 college students from different courses and qualifications, the evaluation priority interest lies in this sample of graduate students given the recent implantanción the Master of Secondary Education at the University of Malaga. In that sense, in our context, from the University of Malaga is a priority this assessment to plan training activities from the beginning in this master program to enable the promotion of ethical responsibilities related to the exercise of a committed and responsible European citizenship socially. All responded to the questionnaire on a collective application class groups.

\section{Instruments}

The instrument used was the "Survey on Values and attitudes on moral issues (VATM)" Trianes (2002) adapted for this purpose. The questionnaire consists of 11 closed items format Likert response what degree they agree with a series of statements. In addition consists of two open questions (12 and 13) to meet potential students in participatory habits any nongovernmental organization (NGO) or carry out joint activity (without financial reward) as well as the reasons for such actions of solidarity, volunteerism and work for others. This questionnaire has adequate psychometric properties being the index of internal consistency for the total scale obtained by calculating the coefficient Alpha $(\alpha)=0.88$. Evaluates personal attitudinal issues such as theft, solidarity, cooperation, international aid, human rights, etc... This is a questionnaire concerning attitude to investigate these issues a high cadence. They also used a scale of self-satisfaction in which the participating students were asked to indicate the degree of satisfaction that reports the educational activity called for solidarity debate, work and reflection on the importance of volunteerism and solidarity in the world today (focused on education issues).

\section{Procedure}

With regard to procedure, it can emphasize that participants have completed the questionnaire in university on a voluntary basis and their data have been entered into SPSS for further analysis. 
Data were collected by two counselors and a researcher at the UMA, by date and time determined by the academic calendar of the University. The questionnaire was completed in the ordinary classes of the various study centers participated in this study after managing the permits, with similar educational policy as to the direction of their centers of study means and the definition of scheduled time development of this activity. It also provided students with the relevant instructions for completing the questionnaire, further ensuring at all times the confidentiality of the data obtained in this study and further explaining the use of tests for research purposes.

Not was limited or temporary space or time devoted to completing the questionnaire by the students to whom were given the opportunity to respond to possible questions and problems of understanding about it or how to fill the proposed questionnaire. The answers in the questionnaire were rigorously checked and recorded prior to the introduction of data into SPSS for further analysis.

\section{Data Analysis}

Descriptive analyzes were performed reflecting percentages, means and standard deviations as well as applying the Student $t$ test for independent samples to see if there were significant differences in assessing attitudes and interest in moral issues based on gender.

\section{Results of Research}

It can be observed from Table 1 that the majority of respondents show that they strongly agreed with the aspects reflected in items 1, 4 and 7 relating to whether the situations described can be considered stealed, violent action or try to avoid there is a conflict $(91.30 \%, 73.60 \%$ and $55.30 \%$ respectively).

It may be emphasize that $66.7 \%$ of young college graduate does not cooperate or participate in an NGO, considering as main reasons for this lack of time or have not yet arisen.As well $58.7 \%$ also does not perform any voluntary activity, helping others without financial reward pointing as reasons: lack of information, lack of time, neglect, has not presented the opportunity, they have not raised and no money for it.

Table 1. Attitudes, values and interests in moral issues (\%).

\begin{tabular}{|c|c|c|c|c|c|}
\hline & & $\begin{array}{l}\text { Strongly } \\
\text { disagree }\end{array}$ & $\begin{array}{l}\text { Somewhat } \\
\text { disagree }\end{array}$ & $\begin{array}{c}\text { Partially } \\
\text { agree }\end{array}$ & $\begin{array}{c}\text { Strongly } \\
\text { agree }\end{array}$ \\
\hline 1. & $\begin{array}{l}\text { If a teen comes into a shopping center, pick up a } \\
\text { videotape, hides and takes it without paying. That is } \\
\text { stealing. }\end{array}$ & 4.8 & 0.8 & 3.2 & 91.3 \\
\hline 2. & $\begin{array}{l}\text { If a young person is buying your house is not paying } \\
\text { taxes by hiding part of their income. This is considered } \\
\text { stealing. }\end{array}$ & 7.9 & 10.3 & 34.1 & 47.6 \\
\hline 3. 1 & $\begin{array}{l}\text { Violent action is to shoot a thief who had entered his } \\
\text { house to steal. }\end{array}$ & 5.6 & 6.3 & 19 & 69 \\
\hline 3.1. & $\begin{array}{l}\text { Right action is to shoot an intruder who had come to } \\
\text { your house to steal. }\end{array}$ & 39.5 & 25.8 & 23.4 & 11.3 \\
\hline 4. & $\begin{array}{l}\text { It is considered a violent act when a student in response } \\
\text { to a beating he received by a group out of high school, } \\
\text { pulls out a knife with which one injures and kills him. }\end{array}$ & 4 & 4.8 & 17.6 & 73.6 \\
\hline 4.1. & $\begin{array}{l}\text { It is considered a righteous action when a student in } \\
\text { response to a beating he received by a group out of } \\
\text { high school, pulls out a knife with which one injures and } \\
\text { kills him. }\end{array}$ & 33.6 & 32 & 26.2 & 8.2 \\
\hline 5. & $\begin{array}{l}\text { If someone approaches you asking for Money when you } \\
\text { shop you feel you must give it. }\end{array}$ & 38.4 & 35.2 & 20 & 6.4 \\
\hline
\end{tabular}




\begin{tabular}{rlcccc}
\hline & & $\begin{array}{c}\text { Strongly } \\
\text { disagree }\end{array}$ & $\begin{array}{c}\text { Somewhat } \\
\text { disagree }\end{array}$ & $\begin{array}{c}\text { Partially } \\
\text { agree }\end{array}$ & $\begin{array}{c}\text { Strongly } \\
\text { agree }\end{array}$ \\
\hline 6. & $\begin{array}{l}\text { When you see the propaganda of the NGOs for help or } \\
\text { Money for projects in disadvantaged I must help. }\end{array}$ & 6.3 & 21.4 & 51.6 & 20.6 \\
\hline 7. & $\begin{array}{l}\text { When you see around you (family, friends, classmates, } \\
\text { etc) will cause a conflict you try to avoid it. }\end{array}$ & 4.9 & 5.7 & 34.1 & 55.3 \\
\hline 8. & The death penalty is fair. & 58.4 & 16.8 & 20.8 & 4.0 \\
\hline 9. & $\begin{array}{l}\text { I agree the town hall give free houses to people who } \\
\text { have suffered a tragedy that has left them homeless. }\end{array}$ & 1.6 & 4.8 & 17.6 & 76 \\
\hline 10. & $\begin{array}{l}\text { Iagree that Europe is close its borders to immigrants } \\
\text { from countries with fewer resources. }\end{array}$ & 42.1 & 35.7 & 18.3 & 4 \\
\hline 11. & $\begin{array}{l}\text { I am ready to interfere if I see some action unjust for } \\
\text { someone. }\end{array}$ & 3.2 & 4.8 & 46.4 & 45.6 \\
\hline
\end{tabular}

The results regarding the degree of satisfaction of participants in educational activities for solidarity, which are shown in Table 2, demonstrate that these activities have been very satisfactory and seem even to have emotional impact and led to a profound reflection on these questions in many of the participants. Presented below in Table 2 mean scores on educational activities for the soliaridad made by these students graduate being $1=$ unsatisfactory; $2=$ rather satisfying; $3=$ reasonably satisfactory and $4=$ highly satisfactory. Participants shown near a strong satisfaction almost exceed 3.5 as observed in Table 2 .

Table 2. Satisfaction of participants in the main activities education for solidarity made.

\begin{tabular}{llc}
\hline & & Average score \\
\hline 1. & Participation in the fórum "Education and Solidarity". & 3.79 \\
2. & Watching the movie "All Starts Today". & 3.91 \\
3. & Design of acts of solidarity by students. & 3.82 \\
4. $\quad$ Debate about the importance of joint action in the & 3.77 \\
5. $\quad \begin{array}{l}\text { Filling in questionnaires virtual campus and analysis/ } \\
\quad \text { discussion of results. }\end{array}$ & 3.42 \\
6. & Preparation of a Wiki cutting supportive news. & 3.79
\end{tabular}

\section{Differences in Attitudes and Interest in Moral Issues Based on Gender}

Next, to determine whether statistically significant differences in attitudes and interests in variable moral issues based on gender analysis has been made mean difference (T of Student). The methodology for analyzing the differences according to gender is of a quantitative questionnaire using the Likert format of four points $(1=$ Strongly Disagree and $4=$ Strongly Agree). The results regarding differences by gender in attitudes and interest in moral issues are presented in Table 3 .

Table 3. Difference in attitudes, values and interests on moral issues by gender.

\begin{tabular}{|c|c|c|c|c|c|}
\hline & & Gender & M & SD & $t$ \\
\hline 1. & $\begin{array}{l}\text { If a teen comes into a shopping center, pick up a } \\
\text { videotape, hides and takes it without paying. That is } \\
\text { stealing. }\end{array}$ & $\begin{array}{c}\text { Man } \\
\text { Woman }\end{array}$ & $\begin{array}{l}3.70 \\
3.86\end{array}$ & $\begin{array}{l}0.70 \\
0.52\end{array}$ & $-3.66^{* *}$ \\
\hline 2. & $\begin{array}{l}\text { If a young person is buying your house is not paying } \\
\text { taxes by hiding part of their income. This is considered } \\
\text { stealing. }\end{array}$ & $\begin{array}{c}\text { Man } \\
\text { Woman }\end{array}$ & $\begin{array}{l}3.21 \\
3.36\end{array}$ & $\begin{array}{l}0.84 \\
0.72\end{array}$ & $-2.73^{* *}$ \\
\hline
\end{tabular}


ISSN 2029-8587

PROBLEMS

OF PSYCHOLOGY

IN THE $21^{\text {st }}$ CENTURY Volume 1, 2012

\begin{tabular}{|c|c|c|c|c|c|}
\hline & & Gender & M & SD & $t$ \\
\hline 3. & $\begin{array}{l}\text { Violent action is to shoot a thief who had entered his } \\
\text { house to steal. }\end{array}$ & $\begin{array}{c}\text { Man } \\
\text { Woman }\end{array}$ & $\begin{array}{l}3.19 \\
3.36\end{array}$ & $\begin{array}{l}0.98 \\
0.84\end{array}$ & $-2.53^{*}$ \\
\hline 3.1. & $\begin{array}{l}\text { Right action is to shoot an intruder who had come to } \\
\text { your house to steal. }\end{array}$ & $\begin{array}{c}\text { Man } \\
\text { Woman }\end{array}$ & $\begin{array}{l}2.31 \\
2.12\end{array}$ & $\begin{array}{l}0.97 \\
0.95\end{array}$ & $2.64^{* *}$ \\
\hline 4. & $\begin{array}{l}\text { It is considered a violent act when a student in } \\
\text { response to a beating he received by a group out of } \\
\text { high school, pulls out a knife with which one injures and } \\
\text { kills him. }\end{array}$ & $\begin{array}{c}\text { Man } \\
\text { Woman }\end{array}$ & $\begin{array}{l}3.36 \\
3.50\end{array}$ & $\begin{array}{l}0.91 \\
0.76\end{array}$ & $-2.32^{*}$ \\
\hline 4.1. & $\begin{array}{l}\text { It is considered a righteous action when a student in } \\
\text { response to a beating he received by a group out of } \\
\text { high school, pulls out a knife with which one injures and } \\
\text { kills him. }\end{array}$ & $\begin{array}{c}\text { Man } \\
\text { Woman }\end{array}$ & $\begin{array}{l}2.24 \\
2.07\end{array}$ & $\begin{array}{l}0.96 \\
0.92\end{array}$ & $2.62^{* *}$ \\
\hline 5. & $\begin{array}{l}\text { if someone approaches you asking for Money when } \\
\text { you shop you feel you must give it. }\end{array}$ & $\begin{array}{c}\text { Man } \\
\text { Woman }\end{array}$ & $\begin{array}{l}1.82 \\
2.00\end{array}$ & $\begin{array}{l}0.90 \\
0.89\end{array}$ & $-2.73^{* *}$ \\
\hline 6. & $\begin{array}{l}\text { When you see the propaganda of the NGOs for help or } \\
\text { Money for projects in disadvantaged I must help. }\end{array}$ & $\begin{array}{c}\text { Man } \\
\text { Woman }\end{array}$ & $\begin{array}{l}2.66 \\
2.99\end{array}$ & $\begin{array}{l}0.82 \\
0.83\end{array}$ & $-5.64^{* *}$ \\
\hline 7. & $\begin{array}{l}\text { When you see around you (family, friends, classmates, } \\
\text { etc) will cause a conflict you try to avoid it. }\end{array}$ & $\begin{array}{c}\text { Man } \\
\text { Woman }\end{array}$ & $\begin{array}{l}3.42 \\
3.52\end{array}$ & $\begin{array}{l}0.77 \\
0.71\end{array}$ & $-2.80^{*}$ \\
\hline 8. & The death penalty is fair. & $\begin{array}{c}\text { Man } \\
\text { Woman }\end{array}$ & $\begin{array}{l}2.01 \\
1.88\end{array}$ & $\begin{array}{l}1.03 \\
0.98\end{array}$ & 0.48 \\
\hline 9. & $\begin{array}{l}\text { I agree the town hall give free houses to people who } \\
\text { have suffered a tragedy that has left them homeless. }\end{array}$ & $\begin{array}{c}\text { Man } \\
\text { Woman }\end{array}$ & $\begin{array}{l}3.44 \\
3.64\end{array}$ & $\begin{array}{l}0.78 \\
0.70\end{array}$ & $-3.26^{* *}$ \\
\hline 10. & $\begin{array}{l}\text { I agree that Europe is close its borders to immigrants } \\
\text { from countries with fewer resources. }\end{array}$ & $\begin{array}{c}\text { Man } \\
\text { Woman }\end{array}$ & $\begin{array}{l}2.22 \\
1.95\end{array}$ & $\begin{array}{l}0.90 \\
0.89\end{array}$ & $3.39^{* *}$ \\
\hline & $\begin{array}{l}\text { I am ready to interfere if I see some action unjust for } \\
\text { someone. }\end{array}$ & $\begin{array}{l}\text { Man } \\
\text { Woman }\end{array}$ & $\begin{array}{l}3.13 \\
3.26\end{array}$ & $\begin{array}{l}0.74 \\
0.68\end{array}$ & $-2.53^{* *}$ \\
\hline
\end{tabular}

Statistical significance. ${ }^{*} p<0.01 ;{ }^{* *} p<0.05$

The results show that there were significant differences in attitudes and interest in moral issues based on gender.

As for the gender variable, overall, the results of mean differences shown in men compared with women more likely to decriminalization of violence if it is in defense of self and less willingness to issuance of prosocial behavior.

\section{Discussion}

The overall objective of this study was to provide an analysis of values and attitudes on moral issues in this sample of graduate students as well as evaluating the impact and satisfaction that has brought them such educational activities for solidarity framed in a draft Educational Innovation "A cross sectional Education study for Solidarity." In this project, which is part of this study involved a multidisciplinary group of 24 teachers from 13 different areas of educational qualifications (34 subjects taught in 13 degrees in Psychology and Education) has proposed to the students in their subjects certain educational cross sectional study activities for solidarity programming tailored to each teacher with the implementation and adaptation of advanced learning methodologies that encourage independent learning, active participation and use of ICT. They are benefiting project a total of 4304 students belonging to 34 subjects of the UMA. 
Regarding the assessment of attitudes and interest in moral issues made in this study, it is striking that there is a group of graduate students who understand that a violent act may be fair, since in our culture that if you decriminalize violence in defense of same. There is no doubt that the decriminalization of violence in terms of defense staff belongs to the realm of morality (Turiel, 1983), while the consideration of an intrinsically unjust and violent action falls within the scope of universal morality which is the main reference Universal Declaration of Human Rights (Schaffer, 2000). Both areas, also called micromoralidad and macromoralidad respectively (Rest, Narvaez, Bebeau and Thoma 1999a, 1999b) may be at odds, especially in young people who have not yet reached a moral identity that characterizes adults with educational level (Blasi, 1993). Prosocial behavior is viewed today as a dimension in that line at one end, while at the other extreme are altruistic behavior (Benítez, 2009). Since altruistic acts may involve some benefit to the person may consider proposing university practices involving behavior for others, even if useful for the students participating. These results are useful in view of an education in values such as solidarity in the university.

All educational activities for solidarity have proved very satisfactory and have emotional impact of participating university students. Of particular interest was the viewing of the movie "It All Starts Today" by Bertrand Tavernier. These graduate students of the Master, in general, have been heavily involved in these activities involve the use of ICT (Information and Communication) and have even produced a short subject with subsequent joint symposium and invitation the entire university community as well as municipalities and other associations. The data reflect how these learning resources involving the use of the word not only image but also are able to facilitate thinking and reflection on the university education system. Specifically, the viewing of the film, as mentioned, has been very satisfactory for the vast majority of students, hence the need and opportunity, as are other studies (López-Barajas and Ruiz, 2000; Pereira, 2006; Vilanou and Colleldemont, 2000), to make use of audiovisual media and cinema to a live address the teaching of values such as solidarity, in addition to being one of the competitions to encourage (digital competence) as stated in the European Higher Education Area superior.

The results also show that it is a viable project. In fact already been carried out and endowed with real practical application not only numerous daily actions of solidarity which has benefited the university community and our environment, but also carried out the design of some of the acts of solidarity proposed by students and supervised by teachers, for example, the successful conclusion of a solidarity Concert, photo exhibition of solidarity and development of cutting short by the students of the Master for what has had the collaboration of the Center Initiatives at the University of Malaga and the Ministry of Education, Science Innovation and Andalusia. It is gratifying to see that it has gone from a purely theoretical in which there have been a series of educational activities for class solidarity developed in the field of real practical application.

About gender, the findings show, in general, less likely in women for the decriminalization of violence if it is in defense of their own (for example, in the item referred to if a person discovers a thief who had entered to steal home and shoots him, women consider a greater extent than men that it is a violent action in defense of even the same; in item 4 issue of whether a student out of high school kills to another in response to a beating he received the women also conceptualized a greater extent than men such action as violent and value to a lesser extent than men this response as a right action). The women participating in this study also show less degree of agreement than men to the question that Europe closing its borders to immigrants from countries with fewer resources. These results are consistent with those obtained in other studies also found greater empathy, spirit of cooperation and moral reasoning in women (Carlo, Roesch and Koller, 1999).

In the times in which we live, social responsibility is increasingly present in more contexts. This responsibility is no longer relegated to the business opening up to other venues such as the university which is necessary to know values and attitudes on moral issues. The New Model for Higher Education brings new methodologies, demands and challenges, where attitudinal skills are one of the fundamental basic skills further. Education in values such as solidarity asserts the need to become the guiding principle of all education, directing the search for comprehensive training of students, promoting ethical values and attitudes and showing, in programming and that compliance with daily life ethical values and socially desirable (Trianes and Fernández, 2001). 
Currently volunteering, solidary and interest in analyzing other social values in Young people are immersed in a context of accelerated development in the academic world (Benítez, 2009; Moral, 2011), which can be one of the most important groups in the development of solidarity actions and work for others. It is important to deepen knowledge and social motivations of university students for optimal development of basic skills such as social and civic life. In addition to confirming the boom there research (Fouce, 2001; García Roca, 1994) that a systematic effort to understand this social phenomenon are the key elements of it are the volunteers and youth organizations that host them. Consistent with this approach, as shown in the work presented, it is worth noting that like the rest of society, academia is no immune to this context of expanding solidarity and voluntary and it is important to know, as reported in this study, what are the values and attitudes towards certain moral issues and social volunteering activities of university students.

This paper argues that we must work values such as honesty, civility and non-violence and solidarity at the university level. Citizenship education is not only characteristic of compulsory education levels, prior to the University. The public also learned per se, without an education in teaching values or unattended in this regard. Ethical training and a full life from a personal standpoint and community capacity to deal with reasoned solutions, complex personal and social situations, require an adequate educational practice, planned and systematic as well as other elements of character training. These approaches are consistent with other studies (García Garrido, 2008; Martinez Buxarrais and Stephen, 2002, Martinez and Esteban, 2005) which advocates a training model that integrates learning university ethics or the construction of the learning moral character lived, as well as learning proper object, or embedded in other learning scientific or cultural character. In any case, these lessons should have their space and time in new degree programs and graduate of the University of the XXI century. Furthermore, the incorporation of a set of ethical responsibilities related to the exercise of a committed and responsible citizenship is consistent with the new profiles placed in the new code-designed professional titles. For this type of learning ethical approach university education student-centered learning and competency seems very successful.

To plan the university educational practice as a professional practice and citizenship requires an assessment and intervention criteria consider ethical and moral. Even without a pedagogical model that defends the inclusion of such content in each and every one of the university educational activities, teachers could try to rethink today's university practices without losing the opportunity to promote the development of learning capabilities that enable significant from an ethical point of view and citizen.

\section{Summing up}

Before concluding it should be noted that although there are different definitions, differences, patterns and speeches about the acquisition of citizenship skills such as solidarity also requires education and training from the university where the students will also protagonist of these acts of solidarity and work for others. Specifically, this study presents the results of the "Questionnaire on values and attitudes on moral issues (VATM)" completed by 226 graduate students belonging to the Master in Teaching Secondary Education and Secondary Education, Training and Teaching of Languages, aged between 22 and 49 years, in order to contribute accurate and effective assessment and intervention on attitudes toward moral issues in this sample of graduate students. This study demonstrates, that the majority of respondents strongly agreed with matters relating, to whether the situations described, can be considered stealing or violent action and are satisfied with the educational activities for solidarity made. They observed a greater tendency to decriminalize violence if in defense of self and less willingness to prosocial behavior in the men. In conclusion, we highlight the importance of early detection and assessment of attitudes and interests to these moral issues with a view to a comprehensive education aimed at improving social coexistence. This assessment will enable the design of actions and training activities that contribute to adquisción transversal competences such as social and civic. 


\section{Acknowledgements}

This study has received financing from Service of Educational Innovation at the University of Málaga (PIE 10-127; Call 2010-2012).

\section{References}

Área, M. (2004). De la Biblioteca al Centro de Recursos para el Aprendizaje e investigación Dirección General de Universidades. [Library Resource Center for Learning and Research General Direction of] Madrid: Ministerio de Educación y Ciencia.

Benítez, A. (2009). La educación en valores en el ámbito de la educación superior. [Values Education in the Area of Higher Education]. Revista Iberoamericana sobre Calidad, Eficacia y Cambio en Educación, 7, 116-129.

Blasi, A. (1993). The development of identity. Some implications of moral functioning. In Noam, G.G. \& Wren, T. E. (Eds.). The moral self. Cambridge: The MIT Press.

Bruner, J. S. (1964). The course of cognitive growth. American Psychologist, 19, 1-15.

Bruner, J. S. (1966). Toward a theory of instruction. Cambridge, Massachusetts: Harvard University Press.

Carlo, G., Roesch, S. C., Koller, S. H. (1999). Similarities and differences in prosocial moral reasoning between Brazilian and AngloAmerican college students. Interamerican Journal of Psychology, 33, 151-172.

Cortina, A. (2000). La educación y los valores. [The education and values]. Madrid: Biblioteca Nueva.

Delors, J. (1997). La educación encierra un tesoro. [Treasure education]. Madrid: Santillana-Unesco.

Drucker, P. F. (1993). La sociedad postcapitalista. [Post-capitalist society]. Barcelona: Apóstrofe.

Escamez, J., Martínez, M., Ortega, P. (2005, noviembre). Formación en valores y construcción del Espacio Europeo de Educación Superior. [Training in values and building the European Higher Education Area]. Ponencia presentada al XXIV Seminario Interuniversitario de Teoría de la Educación SITE, Universitat Politécnica de Valencia, España.

Fouce, J. G. (2001). Voluntarios, exvoluntarios y futuros voluntarios: un estudio descriptivo de sus perfiles y hábitos participativos. [Volunteers, former volunteers and future volunteers: a descriptive study of their profiles and participatory habits]. Apuntes de Psicología, 19, 519-542.

Gagné, R. M. (1965). The conditions of learning. Nueva York: Holt, Rinehart and Winston.

García Garrido, J. (2008). Formar ciudadanos europeos. [European citizens form]. Madrid: Academia Europea de Ciencias y Artes.

García Roca, J. (1994). Solidaridad y voluntariado. [Solidarity and voluntary work]. Santander: Sal Terrae.

Legendre, M. F. (2007). L'évaluation des compétences professionnelles [The evaluation of skills]. En L. Bélair, D. Laveault, D et C. Lebel (dir.), Les compétences professionnelles en enseignement et leur évaluation [Professional skills in teaching and assessment] (p. 169-179). Ottawa: Presses de l'Université d'Ottawa.

Lind, G. (2007). La moral puede enseñarse. Manual teórico-práctico de la formación moral y democrática. [Morality can be taught. Theoretical and practical manual of moral and democratic education]. México: Trillas.

López-Barajas, E., Ruiz, M. (2000). Derechos Humanos y educación. Actas y Congresos. [Human rights and education. Proceedings and Conferences]. Madrid: Universidad Nacional de Educación a Distancia.

Martínez, M., Buxarrais, M., Esteban, F. (2002). La universidad como espacio de aprendizaje ético. [The university as a ethics learning space]. Revista Iberoamericana de Educación, 29, 17-43.

Martínez, M., Esteban, F. (2005). Una propuesta de formación ciudadana para el EEES. [A proposal for civic education to the EHEA]. Revista Española de Pedagogía, 230, 63-84.

Martínez, M., Hoyos, G. (2006). La formación en valores en sociedades democráticas. [Values education in democratic societies]. Barcelona: Ediciones Octaedro.

Moral, F. (2011). Valores sociales y hábitos mediáticos en una muestra de universitarios. [Social values and media habits in a sample of university students]. Electronic Journal of Research in Educational Psychology, 9, 711-730. 
ISSN 2029-8587

PROBLEMS

OF PSYCHOLOGY

IN THE $21^{\text {st }}$ CENTURY Volume 1, 2012

58
Francisco Manuel MORALES RODRÍGUEZ, Maria Victoria TRIANES TORRES. Analysis of Values and Attitudes on Moral Issues in University Students Postgraduate

Moreno González, A. (2008). De la educación socioemocional a la educación en valores. [Social and emotional education to values education]. Madrid: Ministerio de Educación y Ciencia.

Pereira, C. (2003). El cine, nuevo escenario de la educación. [The film, a new stage of education]. En Romañá Blay, M. T. y Martínez Martín, M. (Edit.), Otros lenguajes en educación. [Other languages in education]. Barcelona: ICE-Universitat de Barcelona, pp. 101-105.

Proyecto Tuning 2001-02 y 2003-04. Retrieved 2/12/2011, from http://www.let.rug.nl/TuningProyect/index. htm.

Quintana, J. (2005). La educación en valores y otras cuestiones pedagógicas. [Values education and other pedagogical issues]. Barcelona: PPU.

Rest, J., Narváez, D., Bebeau, M., Thoma, S. (1999a). A neo-Kohlbergian approach to moral judgment: An overview of Defining Issues Test research. Educational Psychology Review, 11, 291-324.

Rest, J. R., Narváez, D., Bebeau, M., Thoma, S. (1999b). Postconventional moral thinking: A neo-Kohlbergian approach. Mahwah, NJ: Erlbaum.

Roegiers, X. (2006). Approche par compétences dans l'enseignement supérieur et cadre européen de qualifications: opportunités, enjeux et dérives. Conférence introductive du colloque La logique des compétences: chance ou danger? [Focus competencies in higher education and European qualifications framework: Opportunities, challenges and diversions. Introductory lecture of the symposium's logic skills: luck or danger], Paris, 17 octobre 2006. Récupéré le 25 septembre 2008 à l'adresse suivante: http://www.bief. be:80/index.php? $s=4 \& r s=22 \&$ uid $=34 \&$ found $=1 \& \lg =$ fr

Schaffer, H. R. (2000). Desarrollo social. [Social development]. México: Siglo XXI Editores.

Touriñán, J. M. (2008). Educación en valores, sociedad civily desarrollo cívico. [Values education, civil society and civic development]. La Coruña: Gesbiblo, S. L.

Trianes, M. V., Fernández, C. (2001). Aprender a ser personas y a convivir. Un programa para secundaria. [Learning to be people and live together. A program for high school]. Bilbao: Desclée de Brouwer.

Trianes, M. V. (2002). Cuestionario sobre Valores y Actitudes en Temas Morales. [Values and Attitudes Questionnaire on Moral Issues]. Extraído el 10 Julio, 2002, de los Apuntes de Psicología de la Educación y sus prácticas de la Plataforma virtual de la UMA.

Turiel, E. (1983). The Development of Social Knowledge: Morality and Convention. Cambridge: Cambridge University Press.

Vilanou, C., Colleldemont, E. (2000). Historia de la educación en valores. [History of education in values]. Bilbao: Desclée De Brouwer.

Vygotski, L. S. (1935). El desarrollo de los procesos psicológicos superiores. [The development of higher psychological processes]. Barcelona: Crítica.

Advised by Maria Ledzińska, Warsaw University, Poland

Received: January 19, 2012

Accepted: February 24, 2012

\begin{tabular}{|c|c|}
\hline $\begin{array}{r}\text { Francisco Manuel Morales } \\
\text { Rodríguez }\end{array}$ & $\begin{array}{l}\text { PhD in Psychology and Bachelor of Labour, Associate Professor (Doctor), Department } \\
\text { of Psychology and Education, School of Psychology, University of Malaga, Campus de } \\
\text { Teatinos s/n, 29071, Malaga, Spain. } \\
\text { E-mail: framorrod@uma.es } \\
\text { Website: http://webdeptos.uma.es/psicoev }\end{array}$ \\
\hline Maria Victoria Trianes Torres & $\begin{array}{l}\text { University Professor, Department of Psychology and Education, School of Psychology, } \\
\text { University of Malaga, Campus de Teatinos s / n, 29071, Malaga, Spain. } \\
\text { E-mail:triatorr@uma.es } \\
\text { Website: http://webdeptos.uma.es/psicoev/ }\end{array}$ \\
\hline
\end{tabular}

